\title{
Straff och andra påföljder för miljöbrott i Finland
}

\author{
Av Heidi Nummela ${ }^{1}$
}

Acting in defiance of certain sections of an environmental law, where there is damage or the risk of damage to the environment or to health, is behavior criminalized in the Penal Code of Finland. All offences which carry prison sentences are covered by the Penal Code. The most serious offences against the environment are included in chapters 48 and 48 a of the Penal Code. In respect of these offences penal scales vary from a fine to a maximum of six years' imprisonment, depending on the seriousness of the criminal act in question. Environmental laws have also penalty sanctions for minor violations. These sanctions may follow merely from the simple act of breaking the law without any reference to consequences.

Corporate criminal liability allows for fines to be imposed on companies. It must be proven that the criminal action has been committed in the course of the company's operations. Who has actually committed the crime does not necessarily need to be identified or proven. A corporate fine is usually imposed in addition to the punishment of the individual offender or offenders. The level of the corporate fine can be anything from 850 to 850.000 euro.

The Penal Code chapter 10 requires that all proceeds of the crime shall be ordered forfeit to the state. This applies to all the crimes committed. If this were not the case - especially in environmental crimes - it might well be worthwhile taking the occasional punishments every now and then because the penalties in the area are actually quite small, usually fines. The Criminal Code, Chapter 10, also requires that instruments of a crime shall be ordered forfeit to the state. If an item or piece of property cannot be forfeited, a forfeiture of equal value may be imposed on the offender.

\section{Om straffmätning i allmänhet}

Om givande av »en rätt dom« är en utmanande uppgift för domstolen, är dess exakta definiering även mera utmanande för åklagaren. Endast i rattfylleribrott

* Title in English: Sanctions and other consequenses for environmental offences in Finland. Original in Swedish. 
och i några andra trafikbrott är rättspraxis mycket vedertagen och längden av domen beror vanligen på alkoholhalten i gärningsmannens blod eller utandningsluft, men visst kan också omständigheterna i rattfylleribrott variera så att straffet inte döms enligt »tabellen«.

Domstolarna har åtminstone inte officiella anvisningar ${ }^{2}$ om straffmätningen i olika brott. Om straffmätningens allmänna principer stadgas i strafflagens (39/1889) 6 kapitel och de enskilda straffen följer långt en vedertagen rättspraxis. Högsta domstolen har sista ordet i straffmätningen. I s.k. traditionella brott finns ganska enhetlig rättspraxis. Däremot i ovanligare brott som i miljöbrott har rättspraxis inte ännu utformats.

\section{Straffarter}

Strafflagens 6 kapitel innehåller stadganden om straffmätningen. De allmänna straffen är ordningsbot, böter, villkorligt fängelse, övervakningsstraff, samhällstjänst och ovillkorligt fängelse. Övervakningsstraffet är en ny straffart och lagen om övervakningsstraff har trätt i kraft den 1.11.2011 (330/2011). För tjänstemän och krigsmän finns några särskilda straff som t. ex. varning, avsättning av tjänstemän och utegångsstraff för krigsmän. Ungdomsstraffet är ett särskilt straff för ett brott som har begåtts av någon som inte ännu fyllt 18 år. Vid vissa brott kan även juridiska personer dömas till bötesstraff. Straffet bestäms inom den straffskala som gäller för brottet i fråga.

Då det är fråga om miljöbrott är de möjliga straffen i praktiken böter eller villkorligt fängelsestraff. Också samhällstjänst och övervakningsstraff kan komma i fråga. För miljöbrott döms sällan något annat än böter, någon gång villkorligt fängelsestraff, samhällstjänst har knappast ens övervägts. Övervakningsstraff har inte heller tillämpats dels för att straffet är nytt men också av samma orsak som samhällstjänst. Båda är nämligen alternativ till ovillkorligt fängelsestraff.

Om miljöbrott begås vid tjänsteutövning kan också avsättning komma i fråga. Gärningen kan vara till exempel underlåtande av myndigheters övervakningsskyldighet eller överskridande av tjänstemans befogenheter. En juridisk person kan dömas till samfundsbot, om någon som hör till ett av dess lagstadgade organ eller annars hör till dess ledning eller utövar faktisk beslutanderätt inom den juridiska personen har varit delaktig i brottet eller tillåtit att brottet har begåtts eller om det i den juridiska personens verksamhet inte iakttagits den omsorg och försiktighet som krävs för att förebygga brottet. Samfundsbot kan även dömas då det inte kan utredas vem gärningsmannen är eller om gärningsmannen av någon annan anledning inte kan dömas till straff. Samfundsbotens storlek kan variera mellan 850 euro och 850000 euro. 


\section{Straffmätning}

Straffet bestäms enligt den straffskala som gäller för brottet i fråga. Vid straffmätningen tar man i beaktande alla de grunder som enligt lagen inverkar på arten och storleken av straffet samt enligheten i straffpraxis (SL kap. $6 \S 3$ ). Den allmänna principen (SL kap. $6 \S 4$ ) är att straffet skall mätas ut så att det står i rättvist förhållande till hur skadligt och farligt brottet är, motiven till gärningen samt gärningsmannens av brottet framgående skuld i övrigt.

Strafflagens 6 kapitel stadgar skärpnings- och lindringsgrunder, skälighetsgrunder samt lindring av straffskalan. Till hjälp i straffmätningen är också lagens förarbeten, speciellt regeringens propositioner, högsta domstolens rättspraxis, rättslitteratur, statistik och de praktiska rekommendationerna. Också de internationella stadganden, som i första hand binder lagstiftaren, har sin inverkan.

\section{Miljöbrottsdirektivet 2008/99/EG}

Genom de lagändringar som trädde i kraft den 25 december 2010, genomfördes EU:s miljöbrottsdirektiv från år 2008 i Finland. Syftet är att säkerställa en hög miljöskyddsnivå inom EU genom att åtgärda miljöbrottsligheten. Miljödirektivet förutsätter att medlemsstaterna åtar sig att införa straffrättsligt ansvar för vissa former av miljöfarliga förfaranden. Det gäller handlingar som skett uppsåtligen eller åtminstone av grov oaktsamhet. Vidare åtar sig medlemsstaterna att införa effektiva, proportionerliga och avskräckande straffrättsliga påföljder för miljöbrottslingar. Sådana påföljder skall även finnas för juridiska personer. ${ }^{3}$

\section{Straffmätningen och brottsrekvisit}

5.1. Allmänt

Med miljöbrott avses vanligen de brott som finns i strafflagens 48 kapitel och de kriminaliseringar som finns i olika speciella miljölagar. I bredare bemärkelse anses också naturresursbrotten i strafflagens kapitel 48 a vara miljöbrott. Även brott som äventyrar andras hälsa och säkerhet (SL kap. 44) kan i vissa fall ha knytningar till miljölagar.

Av kriminaliseringar enligt miljölagarna kan man nämna de förbrytelser som straffas enligt avfallslagens (646/2011) 147 § brott mot avfallslagen. De kan vara olika slag av ringa nedgrävningar eller olaglig hantering av avfall. ${ }^{4}$ Den straffrättsliga påföljden i dessa fall är vanligen 10 dagsböter och polisens straffskala är 6-25 dagsböter. Vid nedskräpning är 50 euros ordningsbot också möjlig. Då det är fråga om förfarande enligt naturvårdslagen (1096/1996) $58 \S$, kan polisen ge böter i strafforderförfarande för naturskyddsförseelse. Dagsböternas normala mängd är då 10 dagsböter när skalan varierar från 5 till $20 .^{5}$ 


\subsection{Gärningar med fängelsestraff}

Miljöbrott togs med i strafflagen då den förnyades. ${ }^{6}$ En av grundprinciperna vid förnyandet var att samla alla allvarligare brott i strafflagen och i synnerhet alla brott med fängelsestraff som påföljd. Straffbestämmelserna gällande miljöbrott hade tidigare varit utspridda på olika håll i lagstiftningen och det hade varit svårt att uppfatta miljön som ett särskilt skyddsobjekt och som en egen helhet. ${ }^{7}$ Man ville också understryka miljöbrottens betydelse och eftersträvade tillräckligt hårda straff med preventiv inverkan. ${ }^{8}$

Det finns sex ${ }^{9}$ olika brott i strafflagens 48 kapitel om miljöbrott. De fyra första gäller förorsakandet av olika slag av förorening, nedskräpning eller annan skadlig påföljd eller fara för miljön. Speciellt kriminaliserade är brott mot avfallslagen och miljöskyddslagen (86/2000). I kapitlets $5 \S$ kriminaliseras allvarligare förbrytelser mot naturvårdslagen och i $6 \S$ förbrytelser mot markanvändnings- och bygglagen (154/1999), lagen om skyddande av byggnadsarvet (498/2010) och lagen om fornminnen (295/63).

\subsubsection{Miljöförstöring}

Brottsrekvisitet i strafflagen kapitel $48 \S 1$ anses utgöra grunden inom miljöbrott. Paragrafen täcker brott som kan vara av mycket olika art och grovhetsgrad. Straffskalan är från böter till högst två års fängelsestraff. I praktiken är straffen böter. Fängelsestraffen kommer i fråga mycket sällan och de är i allmänhet villkorliga.

Enligt Statistikcentralen i Finland ${ }^{10}$ gav tingsrätterna år 2007 i Finland sammanlagt 19 domar gällande miljöförstöringen. I 15 av dessa var straffet böter (i medeltal 49,3 dagsböter). I fyra fall var straffet $i$ genomsnitt fyra månader villkorligt fängelse. År 2008 gav domstolarna 32 domar av vilka 29 var bötesstraff och 3 villkorliga fängelsestraff. Medeltal i böternas storlek var 43,4 dagsböter och i fängelsestraff 2,4 månader. År 2009 gavs 32 bötesstraff (i genomsnitt 44,1 dagsböter) och fyra gånger villkorligt fängelse (i genomsnitt 3,8 månader). År 2010 gav domstolarna 23 domar av vilka två villkorligt fängelsestraff (i genomsnitt 2,8 månader), ett villkorligt fängelsestraff och tilläggsböter (80 st.) och 20 gånger bötesstraff (i genomsnitt 43,3 dagsböter).

Några exempel på nyligen avgjorda brottsfall:

Helsingfors hovrätt 19.9.2008, dom nr 2608, ärendenr R 07/3297

Svaranden hade kört 6 kilometer och en söndrig hydraulisk slang hade läckt olja på vägen. Svaranden hade vetat att slangen var sönder för den hade tidigare exploderat på arbetsfältet. Svaranden var också åtalad för äventyrande av trafiksäkerheten för oljan hade gjort vägen hal. Svaranden dömdes för mil- 
jöförstöring och äventyrande av trafiksäkerheten till 40 dagsböter (normalstraff för äventyrande av trafiksäkerhet 5-40 db).

Södra-Österbottens tingsrätt 6.9.2010, dom nr 10/1667, ärendenr R 10/636

Företagaren hade försummat att ordna sin avfallshantering. Olika slag av byggavfall och problemavfall hade förts till två olika fastigheter och avfallet hade lagrats direkt på marken i söndriga plastsäckar. Ansvarspersonena dömdes för miljöförstöring till 60 dagsböter och dessutom dömdes en person att till staten betala 2000 euro som ekonomisk vinning för brottet.

Helsingfors tingsrätt 14.1.2011, dom nr 11/463, ärendenr R 10/11772

Svaranden hade samlat begagnade bilbatterier som klassificeras som farliga ämnen och hade haft som avsikt att transportera dem till Estland. Han hade inte gjort stadgad anmälan till avfallsregistret och bilens utrustning var inte heller lämplig för transport av farliga ämnen. Han dömdes för brott mot bestämmelserna om transport av farliga ämnen och miljöförstöring till ett gemensamt bötesstraff, 40 dagsböter.

Helsingfors hovrätt 4.3.2011, dom nr 666, ärendenr R 10/506

Svaranden hade samlat fordon och annat skrot som inte mera kunde användas och samlat dem på de fastigheter som han hade i sin besittning. På fastigheterna fanns också olika slags kemikalier. Svaranden hade också bränt avfall där. Myndigheterna hade flera gånger under nästan tio års tid uppmanat honom att söka tillstånd och sluta verksamheten. Det hade konstaterats att verksamheten hade förorenat både mark och grundvatten. Svaranden dömdes för miljöförstöringen till 6 månaders villkorligt fängelse och till att betala till staten 70000 euro som ekonomisk vinning.

\subsubsection{Grov miljöförstöring}

Den grövsta gärningsformen av miljöförstöring är grov miljöförstöring (SL kap. 48 § 2). Grov miljöförstöring är ett såkallat övergrovt brott, det vill säga brott där straffskalan är från fyra månader till sex år fängelse. Detta möjliggör bredare användning av tvångsmedel. Som grov kan miljöförstöring övervägas om 1) den skada eller fara för skada som vållats miljön eller hälsan är synnerligen stor med beaktande av den orsakade eller hotande skadans långvarighet, omfattning eller andra omständigheter eller 2) brottet begås trots en myndighets påbud eller förbud som har givits med anledning av ett förfarande som avses i $1 \S$. Brottet skall alltid bedömas grovt också som en helhet. 
Det är mycket sällan brottet anses uppfylla rekvisiten för grov miljöförstöring. Mellan 2007 och 2008 dömdes ingen för grovt miljöförstöring. År 2009 gavs en dom av tio månaders villkorligt fängelse. Det finns inte statistik gällande domar efter 2010 - men 2012 gavs en dom för grova bedrägerier och grov miljöförstöring. Tingsrätten indelade straffet så att den grova miljöförstöringens andel var två år fängelse, sammanlagt var straffet fyra år ovillkorligt fängelse. Detta är det strängaste straff för miljöbrott som givits i Finland. Domen har inte vunnit laga kraft och ärendet kommer ännu att handläggas i nästa rättsinstans.

Vanda tingsrätt 20.6.2012, dom nr 12/2222, ärendenr 11/2707

Ett bolag som var verksamt inom huvudstadsregionen hade vilselett sina kunder genom att låta förstå att kundernas avfall skulle hanteras lagligt och dessutom fick kunderna fakturor som baserade sig på överdrivna avfallsmängder. Bolagets bokföring avslöjade att man hade avhämtat flytande avfall från hushåll, restauranger och bensinstationer men alla verifikat för deras förande till lagliga emottagningsplatser fanns inte. En del av avfallet hade enligt åklagarna lagrats och behandlats i bolagets lokaler och en del av det fett- och oljeinnehållande vattnet hade hällts i det allmänna kloaksystemet. Bolaget hade i sin lokal en stor bassäng för sand som samlats in från regnvattenbrunnar och sandskiljningsbrunnar. Också andra ämnen sattes $\mathrm{i}$ bassängen $\mathrm{i}$ någon mån och bilarnas tvättvatten släpptes dit. Sanden som avskiljts från vattnet fördes i stor del till sådana avfallsemottagningsplatser som var beredda att ta emot endast rent jordavfall. Avfall hade också delvis förts till fel avfallsemottagningsplatser. Gällande fettavfallet hade mottagarna vilseletts genom att anmäla mängder som inte motsvarade verkligheten.

Tack vare förfarandet hade bolaget sparat enligt åklagarna ca fyra miljoner euro under åren 1999-2008. Summan baserade sig på de kostnader som bolaget inte behövde betala då avfallet behandlades olagligt.

Gärningsmännen, två personer som tillsammans ägde och ledde bolaget, dömdes till fyra års fängelsestraff för två grova bedrägeribrott (SL 36 kap. § 2) och grov miljöförstöring (SL 48 kap. § 2). Personen som skötte om bokföringen och faktureringen dömdes till ett och ett halvt års villkorligt fängelsestraff för medhjälp till ovannämnda brott och en arbetstagare som hade varit i ledande position till 9 månaders villkorligt fängelse för medhjälp till grov miljöförstöring. De arbetstagare som ansågs vara skyldiga dömdes till 80 dagsböters bötestraff för medhjälp till $1 \S$ :s miljöförstöring. Personen som hade fört avfallet till de mottagare som var beredda att ta endast rent jordavfall dömdes till 6 månaders vill- 
korligt fängelsestraff. De två huvudgärningsmännen meddelades också sex års näringsförbud.

Åklagarnas yrkan på samfundsbot förkastades eftersom tingsrätten ansåg att brottet redan förorsakat bolaget tillräckliga följder och därför skulle en utdömd samfundsbot vara oskäligt. Bolaget och huvudgärningsmännen dömdes att till staten förverka som ekonomisk vinning av brott 920000 euro och dessutom ersätta också några andra kostnader som rättegångskostnader. Bolaget och huvudgärningsmännen ålades också att till målsäganden betala sammanlagt ca 280000 euros skadestånd. Domen är inte lagvunnen och behandlingen av ärendet fortsätter i nästa rättsinstans.

\subsubsection{Miljöförseelse}

Den lindrigare formen av miljöbrott är (SL 48 kap. § 3) miljöförseelse. Om miljöförstöringen, med hänsyn till den fara eller skada som har vållats miljön eller hälsan varit mindre betydande eller andra omständigheter vid brottet, bedömda som en helhet är ringa, skall gärningsmannen dömas för miljöförseelse till böter eller fängelse $\mathrm{i}$ högst sex månader. Brottsrekvisiten för miljöförseelse uppfylls också då gärningsman bryter mot föreskrifter som har meddelats med stöd av § 64 miljöskyddslagen eller försummar skyldigheten (enligt $28 \S$ och $29 \S$ miljöskyddslagen) att ansöka om miljötillstånd.

Domstolarna (första instans) dömde år 2007 för miljöförseelse 14 bötesstraff (i genomsnitt 19,1 dagsböter), år 200814 bötesstraff (i genomsnitt 22,1 dagsböter), år 20097 bötesstraff (i genomsnitt 32,1 dagsböter) och år 201012 domar (i genomsnitt 32 dagsböter). ${ }^{11}$

Östra Nylands tingsrätt 19.4.2011, dom nr 11/426, ärendenr R 11/221

Svaranden hade muddrat ett vattenområde och dumpat 750 kubik muddringsmassa i havet i stället för att transportera avfallet till en avstjälpningsplats på det sätt som miljömyndigheterna förutsatt. Svaranden dömdes för miljöförseelse till 30 dagsböter och till att betala staten 2100 euro som ekonomisk vinning.

Östra Nylands tingsrätt 28.8.2012, dom nr 12/884, ärendenr R 12/603

Båda svarandena hade varit verksamma i sitt eget bolag som tillverkade mylla från jordämne som de hade inskaffat från ett annat bolag. Den färdiga myllan hade sålts. Bolaget hade inte det miljötillstånd som miljöskyddslagen förutsätter. Svarandena dömdes till fem dagsböter för miljöförseelse och till att betala staten 4020 euro som ekonomisk vinning (priset för miljötillståndet). 


\subsubsection{Miljöförstöring av oaktsamhet}

Kapitlets $4 \S$ om miljöförstöring av oaktsamhet (SL kap. 48 § 4) kan också anses vara en lindrigare form av miljöförstöring eller till och med av grov miljöförstöring om den skada eller fara som förutsätts uppfylls. Straffskalan är från böter till ett års fängelsestraff.

År 2007 gav tingsrätten endast en dom på 20 dagsböter, år 2008 dömdes två bötesstraff (i genomsnitt 27,5 dagsböter), år 2009 gavs fem domar varav tre bötesstraff (i medeltal 23,3 dagsböter) och i två fall ansågs gärningsmännen skyldiga men lämnades utan straff. År 2010 gavs inga domar för miljöförstöring av oaktsamhet. $^{12}$

Högsta domstolen 20.3.2008, Dnr R 2007/147 (HD:2008:33)

Operatören i ett oljeraffinaderi hade överfört olja från en behållare till en annan. Operatören hade glömt att stänga en ventil med den påföljd att i samband med överföringen rann ca 300 kubikmeter olja på marken och genom marken in i sjön. Oljan fläckade ner stranden på ca 10 kilometers längd. Åbonejdens tingsrätt dömde operatören och tre andra arbetstagare som var i ledande positioner i bolaget för miljöförstöring av oaktsamhet till böter. Senare dömdes bolaget i Högsta domstolen till en samfundsbot på 500000 euro.

\subsubsection{Naturskyddsbrott}

Naturskyddsbrott (SL 48 kap § 5) bestraffas med böter eller upptill två års fängelsestraff. Lindrigare gärningar kan straffas som naturskyddsförseelser enligt naturvårdslagen $(58 \S)$.

År 2007 dömdes inga naturskyddsbrott, år 2008 dömdes 9 gånger till bötesstraff (i genomsnitt 39,4 dagsböter), år 2009 dömdes 6 gånger till bötesstraff (i genomsnitt 25,8 dagsböter) och år 2010 fyra stycken (i genomsnitt 32,5 dagsböter).

År 2007 dömdes för naturskyddsförseelse två gånger (i genomsnitt 15,5 dagsböter), år 2008 sju domar av vilka 5 bötesstraff (i genomsnitt 19,6 dagsböter) och två lämnades utan straff. År 2009 dömdes 15 stycken bötesstraff (i genomsnitt 13,1 dagsböter) och två lämnades utan straff. År 2010 sju gånger (i genomsnitt 22,7 dagsböter) och en lämnades utan straff. ${ }^{13}$

Då miljödirektivet trädde i kraft ändrades också strafflagen kap. $48 \S 5$ så att brott mot den s.k. Cites-förordningen ((EG) Nr 338/97) blev straffbart som naturskyddsbrott. Det är möjligt att mängden naturskyddsbrott därför ökar eftersom gärningar som tidigare betraktades som naturskyddsförseelser nu straffas som naturskyddsbrott. 
Naturskyddsbrott är det allvarligaste brottet mot naturskydd. Detta betyder att oavsett mängden av de skyddade växt- eller djurarterna eller deras ekonomiska värde kommer gärningen att straffas med högst två års fängelsestraff.

Kymmenedalens tingsrätt 7.3.2012, dom nr 12/549, ärendenr R 12/43

Tingsrätten dömde svaranden för naturskyddsbrott för att han hade mot så kallad Cites -förordning (EG) Nr 338/97 köpt flugor, vilka var tillverkade av en skyddad fågels fjädrar. Svaranden hade sålt dem i sin affär och på sina internetsidor. Han hade inte haft de lov som krävs för Cites -produkter.

Lagen hade ändrats under gärningstiden på grund av de ändringar som gjordes i samband med att miljödirektivet ${ }^{14}$ trädde i kraft. Förfarandet dömdes delvis som naturskyddsförseelse och delvis som naturskyddsbrott. Svaranden dömdes till 30 dagsböter och att till staten betala värdet av de sålda produkterna, 540 euro. Också de produkter som han ännu inte hade sålt dömdes till staten.

\subsubsection{Byggnadsskyddsbrott}

I byggnadsskyddsbrott (SL kap 48 § 6) är straffskalan böter till två års fängelse. Ingen kvalificerad form av byggnadsskyddsbrott existerar men lindrigare fall kan också bestraffas som byggnadsförseelse (enligt markanvändnings- och bygglagen (154/1999), kapitel $24 § 185$ ), byggnadsskyddsförseelse (enligt lagen om skyddande av byggnadsarvet (498/2010), kapitel 5 § 23) eller fornminnesförseelse (enligt lagen om fornminnen (295/63), kapitel $4 \S 25$ ).

Under åren 2007-2009 dömdes inga straff för byggnadsskyddsbrott, år 2010 dömdes för ett till 25 dagsböter. ${ }^{15}$

Åbo tingsrätt 8.10.2009, dom nr 09/4132, ärendenr R 09/2884

Svarandena hade huggit ned 42 träd utan de tillstånd som krävs enligt markanvändnings- och bygglagen. Träden hade huggits ned vid strandzonen där ett åtgärdsförbud var i kraft. Svarandena dömdes för byggnadsförseelse till 12 dagsböter.

\section{Samfundsbot}

Reglerna gällande samfundsbot i strafflagens 9 kapitel tillämpas då det är fråga om miljöbrott enligt 48 kapitlet. Miljöbrott begås ofta vid företagsverksamhet. ${ }^{16}$ För att straffet skall påverka preventivt, måste det vara riktat till den som faktiskt ansvarar för verksamhet. Bolaget måste dömas till samfundsbot om förutsättningarna uppfylls. Samfundsbotens storlek har stannat på relativt låg nivå. 
Storleken av en samfundsbot fastställs enligt arten och omfattningen av den juridiska personens underlåtelse eller ledningens andel, om vilka stadgas i 2 §, samt enligt den juridiska personens ekonomiska ställning.

Om grunderna för bestämmandet av samfundsbot stadgas i 9 kapitlet $6 \S$. »Vid bedömningen av betydelsen av underlåtelsen och ledningens andel beaktas brottets art och svårhet, den brottsliga verksamhetens omfattning, gärningsmannens ställning i den juridiska personens organ, i vilken mån åsidosättandet av den juridiska personens skyldigheter utvisar likgiltighet för stadganden i lag eller myndigheternas bestämmelser, samt övriga i lag stadgade straffmätningsgrunder. Vid bedömningen av den juridiska personens ekonomiska ställning beaktas dess storlek och soliditet, verksamhetens ekonomiska resultat samt övriga omständigheter som väsentligt påverkar bedömningen av den juridiska personens ekonomi.«

År 2010 dömdes två samfundsbot i miljöbrott (i genomsnitt 4000 euro), år 2009 dömdes inga samfundsbot, år 2008 en samfundsbot (8 000 euro) och år 2007 tre stycken (i genomsnitt 7166 euro). ${ }^{17}$

Med samfundsbot eftersträvas en konkret och tillräcklig påföljd också för företaget, eftersom böter som enskilda personer inom företaget döms till, knappast i praktiken påverkar företags verksamhetsätt. En gång har en stor samfundsbot på 500000 euro dömts för miljöförstöring av oaktsamhet. Då var det fråga om ett av landets största företag. ${ }^{18}$

\section{7. Övriga påföljder}

Brottet kan ha andra straffrättsliga påföljder förutom det egentliga straffet. Vid straffmätningen kan domstolen ta i beaktande de andra följder som brottet har lett till eller domen medför (SL 6 kap. 7 §). Gärningsman kan också förpliktas att betala skadestånd eller meddelas näringsförbud. I strafflagens 10 kapitel stadgas om förverkande av vinning (2 §), utvidgat förverkande av vinning (3 §), förverkande av hjälpmedel vid brott (4 §), förverkande av annan egendom (föremål och egendom som har framställts, tillverkats eller fåtts till stånd genom ett brott eller som har varit föremål för brott) $(5 \S)$ och förverkande av värde $(8 \S)$.

\subsection{Förverkande av vinning}

Den viktigaste förverkandepåföljden kan anses vara konfiskerande av den vinning som gärningsman eller någon annan har fått av brottet. Lagen förutsätter att vinning alltid bör tas bort från brottslingen oavsett grovheten av brottet eller om det är straffbart av oaktsamhet eller uppsåt. Lagen ger inte några konkreta anvisningar hur man beräknar vinningen. Lagpunkten konstaterar att »Om beloppet av 
den vinning brottet har medfört inte alls eller endast med svårighet kan utredas, skall beloppet uppskattas med beaktande av brottets art, omfattningen av den brottsliga verksamheten och övriga omständigheter«. Lagen ger ganska mycket prövningsfrihet åt domstolen vid övervägandet av vinningen. I miljöbrott kan vinningen av olagligt förfarande bestå t.ex. av de sparade kostnader då man inte har hanterat avfallet lagligt, investeringskostnader, tillståndavgifter och affärsvinst. Om målsäganden inte kräver ersättning för den skada som brottet medfört skall vinningen också till den delen dömas till staten.

\subsection{Förverkande av hjälpmedel vid brott}

En allmän princip är att föremål och egendom som har använts för begående av ett brott kan dömas förverkade till staten (SL kap. 10 § 4). I miljöbrott kan det vara t. ex. om de redskap som har använts vid olaglig hantering eller transportering av avfall. När det är fråga om jaktbrott som är ett naturresursbrott (SL kap. 48 a) finns det speciella regler för förverkande av de medel som använts vid olaglig jakt.

\subsection{Förverkande av annan egendom}

Enligt 5 § skall föremål och egendom som har framställts, tillverkats eller fåtts till stånd genom ett brott eller som har varit föremål för brott dömas förverkade till staten, om innehavet av föremålet eller egendomen är straffbart. Förverkandet av ovannämnda egendom är också möjligt t. ex. för att nya brott skall kunna förebyggas, och föremålet är särskilt lämpat som brottsobjekt eller för brottslig användning, för att syftet med bestämmelser om reglering eller om import eller export skall kunna uppnås, eller om föremålen eller egendomen har egenskaper som gör dem skadliga för hälsan eller miljön. Förverkandet kan också ske för att syftet med bestämmelser om skydd av naturen eller miljön skall kunna uppnås. Ett kärl, emballage eller något annat som har använts för förvaring av föremål eller egendom som skall dömas förverkade kan också förklaras förverkat, om förverkandepåföljden inte annars kan verkställas utan svårighet.

Förverkandeyrkan kan drivas trots att åtal inte har väckts: Tullen hade beslagtagit en stor mängd av produkter som hade tillverkats av delar av djur eller växter som var skyddade med Cites -avtalet. Förundersökningen begränsades och avslutades för det var tydligt att man aldrig skulle påträffa gärningsmän. Åklagaren yrkade att produkterna skulle förverkas till staten och Helsingfors hovrätt dömde enligt åklagarens yrkande (2.7.2010, nro 1867, Dnr R 10/1129). 


\subsection{Förverkande av värde}

Om föremål eller egendom som avses i 4 eller $5 \S$ inte döms förverkade på grund av de inskränkningar som bestäms i $6 \S 1$ mom. eller på grund av att föremålet eller egendomen har dolts eller annars inte går att få tag på, kan i stället för föremålet eller egendomen förverkas till staten dess värde, antingen helt eller delvis (SL kap. 10 § 8).

Naturvårdslagen $59 \S$ har speciella regler gällande förverkandet av värdet. Föremålet för brott skall dömas till staten och dessutom skall det värde som ett fridlyst djur eller en fridlyst växt har som representant för sin art också dömas förverkat. Miljöministeriet i Finland har fastställt riktgivande värden för fridlysta djur och växter.

\section{Oljeutsläppsavgift}

I Finland har miljömyndigheterna (olika myndigheter har olika ansvarsområden) inte några sanktioner mot personer som förfar olagligt. Ett undantag är oljeutsläppsavgiften. ${ }^{19}$ Oljeutsläppsavgiften påförs av gränsbevakningsväsendet i de fall där det släppts ut olja från fartyg. Oljeutsläppsavgiften påförs den fysiska eller juridiska person som vid tidpunkten för överträdelsen är fartygets ägare eller redare. Oljeutsläppsavgiften bestäms utifrån utsläppets omfattning och fartygets bruttodräktighet enligt den avgiftstabell som utgör bilaga till lagen. Oljeutsläppsavgiften är subsidiärt till straffprocessen och kan inte påföras den som genom en lagakraftvunnen dom har dömts till straff för oljeutsläppet i fråga (miljöskyddslagen för sjöfarten (1672/2009)). Den påförda avgiften är mycket större än bötesstraff i straffprocessen. Enskilda summor har varierat från 4000 euro till 22000 euro. $^{20}$

\section{Till slut}

Tillsvidare har endast den konkreta skadan eller det hot för skada som konstaterats tagits i beaktande vid straffmätning. Själv tycker jag att man vid definiering av straffnivån också skulle kunna beakta ovissheten av miljöskadornas långvarighet och omfattning samt de oförutsebara hälsorisker som miljöbrott kan förorsaka. I de nuvarande miljöbrottsparagraferna är den eftersträvade ekonomiska vinningen eller gärningens planmässighet inte kvalificeringsgrunder. De kan man nog ta i beaktande i helhetsbedömningen men då har grunderna inte samma vikt.

Påföljden i miljöbrott är i regel bötesstraff. Kravet på enhetlig rättspraxis kan i miljöbrott också leda till att straffen förblir lindriga eftersom miljöbrott är mer sällsynta och ofta nya också för domstolen. 
För en privatperson kan bötesstraff samt förverkande av vinningen i verkligheten vara en betydande och tillräcklig påföljd. Straffmätningen kan också ha betydelse då det är fråga om miljöbrott som begåtts vid företagsverksamhet. Faran är nämligen att det kan löna sig att försöka fungera olagligt om påföljden då man blir fast är högst att ersätta de kostnader som har undvikits och ett lindrigt bötesstraff. För det är nästan säkert att man aldrig blir fast för alla brott man begått.

\section{Noter}

1. Heidi Nummela arbetar som häradsåklagare vid Östra Nylands åklagarämbete. Hon har arbetat inom åklagarväsendet ca 15 år varav 2,5 år vid Riksåklagarämbetet som överinspektör. Sedan 2004 har hon specialiserat sig i miljöbrottsfrågor och arbetat som nyckelåklagare för miljöbrott. I hennes arbete ingår att driva både miljö- men också andra brottsärenden i rättsprocessen, rättspraxis i anknytning till miljöbrott, uppföljning av lagstiftningen och den internationella utvecklingen samt utbildning av åklagare och rådgivning.

Nummela har medverkat i olika nationella arbetsgrupper gällande miljöbrott som t.ex. den Nationella uppföljningsarbetsgruppen för miljöbrott. Hon har också deltagit som representant för åklagarväsendet i Finland i olika internationella evenemang. Nummela är medlem i The network of prosecutors on environmental crime (ENPRO) sedan 2008. Nätverkets medlemmar är länderna runt Östersjön.

2. Det har gjorts olika utredningar om rättspraxis och om faktorer som påverkar straffmätningen t. ex. Kouvola hovrättens utredning 28.9.2007 som kan vara till hjälp vid straffmätningen.

3. Europeiska Unionens officiella tidning L 328/28; EUROPAPARLAMENTETS OCH RÅDETS DIREKTIV 2008/99/EG av den 19 november 2008 om skydd för miljön genom straffrättsliga bestämmelser.

4. Suomen kansallinen ympäristörikosseurantatyöryhmä (30.6.2011); Vuosiraportti vuoden 2009-2010 ympäristörikoksista Suomessa (Rapport över miljöbrott i Finland 20092010/Finlands nationella grupp för övervakning av miljöbrott).

5. Handbok i bestämmande av påföljder vid strafforder- och förseelsebotförande/Inrikesministeriets polisavdelning 2006.

6. Lagen 578/1995.

7. Tidigare miljöbrottkriminaliseringar var i utspridda miljölagar t. ex. avfallshanteringslag (673/78) 6 kap, luftskyddslag (67/82) 6 kap och vattenlag (264/61) 13 kap.

8. Regeringens proposition till riksdagen RP 94/93 rd.

9. Det finns också $10 \S »$ Från utländska fartyg i den ekonomiska zonen begångna miljöbrott« som inte behandlas här.

10. Finlands officiella statistik (FOS): Åtalade, dömda och straff [e-publikation]. ISSN=1798-6699. Helsingfors: Statistikcentralen [hänvisat: 29.9.2012]. Åtkomstsätt: http://www.stat.fi/til/syyttr/tau_sv.html.

11. Finlands officiella statistik (FOS): Åtalade, dömda och straff [e-publikation]. ISSN=1798-6699. Helsingfors: Statistikcentralen [hänvisat: 29.9.2012]. Åtkomstsätt: http://www.stat.fi/til/syyttr/tau_sv.html. 
12. Finlands officiella statistik (FOS): Åtalade, dömda och straff [e-publikation]. ISSN=1798-6699. Helsingfors: Statistikcentralen [hänvisat: 29.9.2012]. Åtkomstsätt: http://www.stat.fi/til/syyttr/tau_sv.html.

13. Finlands officiella statistik (FOS): Åtalade, dömda och straff [e-publikation]. ISSN=1798-6699. Helsingfors: Statistikcentralen [hänvisat: 29.9.2012]. Åtkomstsätt: http://www.stat.fi/til/syyttr/tau_sv.html.

14. Europeiska Unionens officiella tidning L 328/28; EUROPAPARLAMENTETS OCH RÅDETS DIREKTIV 2008/99/EG av den 19 november 2008 om skydd för miljön genom straffrättsliga bestämmelser.

15. Finlands officiella statistik (FOS): Åtalade, dömda och straff [e-publikation]. ISSN=1798-6699. Helsingfors: Statistikcentralen [hänvisat: 29.9.2012]. Åtkomstsätt: http://www.stat.fi/til/syyttr/tau_sv.html.

16. Regeringens proposition till riksdagen RP $94 / 93 \mathrm{rd}$.

17. Finlands officiella statistik (FOS): Åtalade, dömda och straff [e-publikation]. ISSN=1798-6699. Helsingfors: Statistikcentralen [hänvisat: 29.9.2012]. Åtkomstsätt: http://www.stat.fi/til/syyttr/tau_sv.html.

18. Högsta domstol 20.3.2008 dnr R2007/147.

19. Ett annat undantag är försummelseavgift (avfallslagen $131 \S$ ) som behandlas inte här.

20. Raportti vuosien 2009-2010 ympäristörikoksista Suomessa/Suomen kansallinen ympäristörikosseurantatyöryhmä 30.6.2011 s. 19 (Rapport över miljöbrott i Finland 2009-2010/Finlands nationella grupp för övervakning av brottspåföljder i miljöbrott).

\section{Källförteckning}

Europeiska Unionens officiella tidning L 328/28; EUROPAPARLAMENTETS OCH RÅDETS DIREKTIV 2008/99/EG av den 19 november 2008 om skydd för miljön genom straffrättsliga bestämmelser.

Regeringens proposition till riksdagen RP 94/93 rd (Hallituksen esitys Eduskunnalle rikoslainsäädännön kokonaisuudistuksen toisen vaiheen käsittäviksi rikoslain ja eräiden muiden lakien muutoksiksi 94/1993.).

Handbok i bestämmande av påföljder vid strafforder- och förseelsebotförande/Inrikesministeriets polisavdelning 2006.

Kouvola hovrätts utredning 28.9.2007 (Kouvolan hovioikeuspiirissä tehty selvitys rangaistuskäytännöstä ja rangaistuksen mittaamiseen vaikuttavista seikoista toistuvasti tehtävissä rikoksissa 28.9.2007.).

Raportti vuosien 2009-2010 ympäristörikoksista Suomessa/Suomen kansallinen ympäristörikosseurantatyöryhmä 30.6.2011. (Rapport över miljöbrott i Finland 2009-2010/Finlands nationella grupp för övervakning av miljöbrott).

\section{Rättspraxis}

Högsta domstolen 20.3.2008, Diarienr R 2007/147 (HD:2008:33).

Helsingfors hovrätt 19.9.2008, nr 2608, ärendenr R 07/3297

Helsingfors hovrätt 2.7.2010, nro 1867, ärendenr R 10/1129

Helsingfors hovrätt 4.3.2011, nr 666, ärendenr R 10/506

Åbo tingsrätt 8.10.2009, dom nr 09/4132, ärendenr R 09/2884 
Södra-Österbottens tingsrätt, 6.9.2010, dom nr 10/1667, ärendenr R 10/636

Helsingfors tingsrätt 14.1.2011, dom nr 11/463, ärendenr R 10/11772

Östra Nylands tingsrätt 19.4.2011, dom nr 11/426, ärendenr R 11/221

Kymmenedalens tingsrätt 7.3.2012, dom nr 12/549, ärendenr R 12/43

Vanda tingsrätt 20.6.2012, dom nr 12/2222, ärendenr 11/2707

Östra Nylands tingsrätt 28.8.2012, dom nr 12/884, ärendenr R 12/603

Finlands officiella statistik (FOS): Åtalade, dömda och straff [e-publikation].

ISSN=1798-6699. Helsingfors: Statistikcentralen [hänvisat: 29.9.2012].

Åtkomstsätt: http://www.stat.fi/til/syyttr/tau_sv.html. 